\section{THE PREVENTION OF ENTERIC FEVER IN ARMIES.}

Bx GEORGE D. N. LEAKE, M.R.C.S., L.R.C.P., D.P.H., Colonel, R.A.M.C.

When I proceeded to Bermuda as senior medical officer, Surgeon-General Jameson, C.B., the Director-General Army Medical Service at that time, directed my attention to the great prevalence of enteric fever there, and requested me to spare no pains in my efforts to cope with it.

After being in Bermuda a year or so, I arrived at the conclusion that the dry-earth latrines were responsible for nearly all the cases which occurred in barracks-by inhalation or deglutition, when using the latrines, of the germs-so, acting on this conviction, I strenuously advocated their total abolition from all the barracks in the islands, and the introduction of the water-carriage system.

My recommendations were approved of by the General Officer Commanding Sir George Barker, K.C.B., Colonel Moore, C.R.E. (the pioneer, I believe, of the water-carriage system in Bermuda), and by his successor Colonel Bor, C.R.E., who most ably supported me throughout a very difficult (and expensive) undertaking. . Some considerable time necessarily elapsed before the dry-earth latrines could be done away with, so it was incumbent on me in the meantime to render them as little pernicious as possible.

This was done by disinfecting every portion of the latrines and urinals with a ro per cent. solution of carbolic acid applied in large quantities by means of a watering-pot and rose once or twice a week, and when the water-carriage system was established the same process was continued but less frequently.

In connexion with this the following table will, I think, be of interest :-

\begin{tabular}{|c|c|c|c|c|}
\hline Year. & $\begin{array}{l}\text { Average } \\
\text { Annual } \\
\text { Strength. }\end{array}$ & $\begin{array}{c}\text { Admissions } \\
\text { for } \\
\text { Enteric Fever. }\end{array}$ & $\begin{array}{c}\text { Deaths } \\
\text { from } \\
\text { Enteric Fever. }\end{array}$ & Remarks. \\
\hline 1895 & $\mathrm{r}, 447$ & 107 & 20 & \\
\hline $\mathbf{r 8 9 6}$ & $x, 385$ & 27 & 4 & \\
\hline $\mathbf{8 9 9 7}$ & $x, 52 x$ & 34 & 7 & \\
\hline 8898 & $x, 73^{\circ}$ & 26 & 4 & In the year \\
\hline 1899 & $r, 78 r$ & 20 & o & $\mathrm{r}, 444$ troops \\
\hline 1900 & $\mathrm{x}, 444$. & 8 & o & West Indian. \\
\hline
\end{tabular}

In 1897 all filters in barracks were abolished, and in 1899 boiling the drinking water was no longer resorted to, as I considered filtering and boiling unnecessary. with the water supply we.had-rain water collected on catches stored in tanks and kept in a good sanitary state.

Undoubtedly boiling the water for drinking purposes is essential under certain circumstances, but I question its atility in preventing to any great extent the incidence and spread of enteric fever in barracks or in the field.

I lay much more stress on keeping the latrines, etc., in a perfect sanitary condition, but I know from experience what a very difficult duty this is; the medical officer must give the matter his personal superintendence, and to do it effectually his sanitary zeal must be above the average. I hold that the sedentary life and close atmosphere on board ship predispose soldiers to enteric fever; so, also, does the vitiated air of tents, which may account for enteric fever being so prevalent amongst recent arrivals at a foreign station, and its breaking out so frequently on going into camp from barracks.

The fact of'men being so thirsty as to drink muddy and dirty-looking water rather than wait for pure water, suggests to me that Nature may only be asserting herself, the demands of the system being paramount, and that to withhold water under such conditions is, paradoxically speaking,'to add fuel to the fire. May not the liquid, perhaps, be salutary, by distending the intestines and serving as a medium for any microorganisms already introduced to float in and pass away with the excreta; and may not the contrary, the comparative emptiness of the canal and probable apposition of its walls, tend to foster them?

Again, may not the secretion or excretion of the bile with its antiseptic and germicidal properties be thereby checked? Possibly there would be no enteric fever if the liver acted healthily.

\section{THE DISINFECTION OF NEW CLOTHES.}

By Sir CHARLES A. CAMERON, C.B., M.D., Medical Officer of Health, Dublin.

I HAVE been able in several instances to satisfy myself that new clothes were the vehicle of the infective matter of scarlet fever; but I shall only mention one of them.

A young lady, residing in a sequestered part of the county of Wicklow, contracted scarlet fever. No case of the disease had for a long time previously occurred in or near the district, and the young lady had not been from home for several months. Her mother had keen three times in Dublin shortly before her daughter's illness. On each occasion her visit was to a dressmaker, and on the last visit she brought home a new dress. It was handled and admired by her daughter, who soon after became ill from scarlet fever, a disease from which her mother and all the other members of her family had suffered several years before. Circumstances led me to inquire into the origin of the infection, and I ascertained that in the family of the dressmaker there was a severe case of scarlet fever. It was admitted to me that the making of the dress had been chiefly carried on in the room in which the patient was located. There seems to be little room for doubting that the dress was infected by this patient, and that the materies morbi infected the lady's daughter. I could describe many similar cases.

The recruits of the Royal Irish Constabulary are located in a large barracks situated in the Phœnix Park, Dublin. The barracks are large, well ventilated, and provided with the most approved sanitary accommodation, and are situated in a park, yet for many years past the recruits have been peculiarly liable to contract scarlet fever, from which disease the other inmates of the barracks rarely suffer.

The clothes of the recruits are largely made by women for the contractor who supplies them to the constabulary. It occurred to me that the new clothes supplied to the recruits were probably the means of conveying infection to them. Accordingly, I recommended that the clothes should be sterilised before they were received into the barracks. The recommendation was adopted, and apparently with a good result. The sterilisation commenced at the end of April, I90I, and the following shows the number of cases of scarlet fever in each month of that year and the previous one: I900-January, 3; February, 7 ; March, 2 ; April, 4; May, 1 ; June, 4; July, 3 ; August, I ; September, o; October, 3 ; November, 4 ; December, 11. I90I-January, 6; February, 10; March, 9; April, 6; May, 4. From May i 5 th up to the present (January, I 902 ) no further cases have occurred.

It would be desirable to have all clothes, made by tailors and dressmakers, sterilised, and certificates given that they had been subjected to that process before the articles were sent home. The cost of sterilising is trifling, and the process could be carried out in the disinfecting stations of the sanitary authorities or by private persons provided with the necessary appliances. No doubt some articles of ladies' apparel might be injured by the process, but they would be exceptional.

\section{ON DIPHTHERIA ANTITOXIN ERUPTIONS.}

By ARTHUR STANLEY, M.D., B.S.LoND., D.P.H., Health Officer of Shanghai.

THE following observations were made on a series of 500 cases cases of diphtheria during two years' work in a diphtheria ward at the North-Western Hospital of the Metropolitan Asylum Board. All the cases were treated with antitoxin, and the diagnosis of doubtful cases was verified by bacteriological examination. The total number of deaths in the series was 8o, a death-rate of 16 per cent. The antitoxin was 